\title{
Groundwater Chemistry Regulated by Hydrochemical Processes and Geological Structures: A Case Study in Tongchuan, China
}

\author{
Xinyan $\mathrm{Li}^{1,2}$, Hao Wu ${ }^{1,2}$, Hui Qian ${ }^{1,2, *}$ and Yanyan Gao ${ }^{1,2}$ \\ 1 School of Environmental Science and Engineering, Chang'an University, Xi'an 710054, China; \\ lixinyan@chd.edu.cn (X.L.); wuhao@chd.edu.cn (H.W.); gaoyanyan3689@163.com (Y.G.) \\ 2 Key Laboratory of Subsurface Hydrology and Ecological Effect in Arid Region of Ministry of Education, \\ Chang'an University, Xi'an 710054, China \\ * Correspondence: qianhui@chd.edu.cn; Tel: +86-029-8233-9327
}

Received: 22 December 2017; Accepted: 14 March 2018; Published: 19 March 2018

\begin{abstract}
Knowledge of hydrochemical processes in groundwater helps to identify the relationship between geochemical processes and groundwater quality as well as to understand the hydrochemical evaluation of groundwater, which is important for the sustainable management of groundwater resources. This study aims to identify the chemical characteristics of groundwater in the area of Tongchuan City, China. A total of 58 groundwater samples were collected. A hierarchical cluster analysis divided samples into three clusters and six sub-clusters (cluster 1a, 1b, 2a, 2b, 3a, 3b) according to hydrochemical facies. Graphical plots of multiple ionic ratios, saturation indices, and ion exchange indices were employed to examine hydrochemical processes that result in different hydrochemical facies of each cluster. Results show the predominance of carbonate and silicate weathering in cluster 1 , silicate weathering in cluster 2 , and carbonate weathering in cluster 3 . Ionic exchange is a ubiquitous process among all clusters. The distribution of clusters is related to the regional geology, which may result in different hydrochemical processes. Two stratigraphic sections identify the differences in hydrochemical processes resulting from complex stratum structures and varied aquifer media. Cluster 2a shows an interesting difference in water chemistry along the groundwater flow path. Further study by oxygen and hydrogen isotope indicated that mixing between Quaternary and the Permian aquifers resulting from faulting is the main reason for the distinctive characteristic of cluster $2 a$.
\end{abstract}

Keywords: hydrochemistry; hydochemical process; groundwater flow; Tongchuan; fault

\section{Introduction}

Groundwater is vital to the development of most arid and semiarid regions due to limited precipitation and surface water [1,2]. Rational utilization and sustainable management of groundwater is particularly important in these areas [3]. In natural hydrological cycling, groundwater interacts with the surrounding rocks causing a variety of hydrogeochemical processes that alter groundwater chemical components. Study of the hydrogeochemical processes has been an area of interest in the past few decades, as chemical variation of groundwater can reveal the interaction between groundwater and environment and provide a scientific basis for water resource management. Kumar et al. [4] have identified that simple dissolution, mixing, weathering of carbonate and silicate minerals, ion exchange, and interaction with surface water are the important hydrogeochemical processes that control groundwater quality in Delhi, India. Sonkamble et al. [5] have identified that carbonate, dolomite, calcite, and silicate weathering are the predominant hydrogeochemical processes in the proximity basalt area, but silicate weathering is dominant in proximity granite area, both in the 
Deccan Volcanic Province in India. Moya et al. [6] used multivariate statistical techniques to identify hydrological processes within the Eromanga and Galilee basins, resulting in the recognition of inter-aquifer mixing. Brkić et al. [7] used hydrochemical and isotope data to learn groundwater flow and residence time, which explains hydrogeochemical variations in a part of the aquifer system of Eastern Slavonia. Kim et al. [8] evaluated the complex hydrogeochemical processes occurring in a salinized aquifer during freshening in the Red River delta aquifer using a multiple end-members mixing model, which successfully found that mixing processes among paleo-seawater, infiltrating rain, and the K-rich groundwater controlled the groundwater chemistry. Thus, knowledge of hydrogeochemical processes can help better understand chemical characteristics of groundwater, which can lead to a reasonable allocation of groundwater resources for many different purposes such as in agriculture, industry, and environmental protection.

Many parts of China, especially arid and semi-arid regions, rely heavily on groundwater resources. Tongchuan is a rapidly growing city in north China and is located on the south edge of the Loess Plateau. With the rapid development in industry and agriculture, groundwater is over-exploited to meet the increasing demand, leading to problems with both groundwater quality and quantity. Due to agricultural activity, the groundwater in the area has been polluted by nitrate $[9,10]$. Knowledge of hydrochemical processes of groundwater can provide an effective approach to protect, treat, and restore contaminated groundwater [11,12]. Previous studies examined the geological-hazards and groundwater pollution sources $[9,10,13,14]$, however, the hydrogeochemical processes in Tongchuan remain unknown. The geologic structure is complicated, with two faults cross-cutting the study area. Geological structures play a substantial role in many qualitative and quantitative studies of hydrogeological processes $[15,16]$. Rajabpour et al. [16] investigated the influence of the North Tabriz Fault on the alluvial aquifer northwest of Tabriz, Iran, which showed quite different hydrochemical properties on either side of the fault. Hagedorn and Whittier [17] used the geochemical data to identify solute sources and mixing processes between various water types in a region that experienced multiple lithospheric extension events, and found a remarkable heterogeneity in alluvial spring and groundwater chemistry. However, hydrochemical studies are concerned with the impact of mineral components on groundwater chemistry and evolution of hydrochemical processes along the flow, but ignore the impact of geological conditions on groundwater chemistry. Hence, this study was carried out to identify the hydrochemical processes that control the chemistry of groundwater and to analyze the impact of geologic structures on hydrogeochemistry in the Tongchuan region.

\section{Study Area}

The study area is located in the southeastern part of Tongchuan City in Shaanxi Province, which is situated on the southern edge of the Loess Plateau in China [18]. It lies between longitude $108^{\circ} 50^{\prime}-109^{\circ} 00^{\prime} \mathrm{E}$ and latitude $34^{\circ} 50^{\prime}-35^{\circ} 00^{\prime} \mathrm{N}$ (Figure 1) with altitudes between 900 and $1350 \mathrm{~m}$ above mean sea level. The topography slopes from northwest (NW) to southeast (SE). The study area belongs to the warm semi-arid to semi-humid climate and has hot, rainy summers but cold and dry winters [19]. The average annual rainfall is $537.86 \mathrm{~mm}$ (more than $50 \%$ of which occurs from July-September) [20], and the annual evaporation is $1445.65 \mathrm{~mm}$. The mean minimum and maximum temperatures are 3 and $23^{\circ} \mathrm{C}$, respectively. Tectonically, Tongchuan region belongs to a transition zone between the Ordos platform and Fen-Wei Graben $[13,21]$. The region contains three major geographical regions, such as the loess gully region, loess platform, and terraced valley region. Four NW-SE running rivers pass through the region draining into the Shichuan River. Little water can be utilized from these rivers because of low river levels. Groundwater is the primary source of water for daily life and agricultural production in the region, especially in the loess-covered areas [9]. 


\section{Legend}

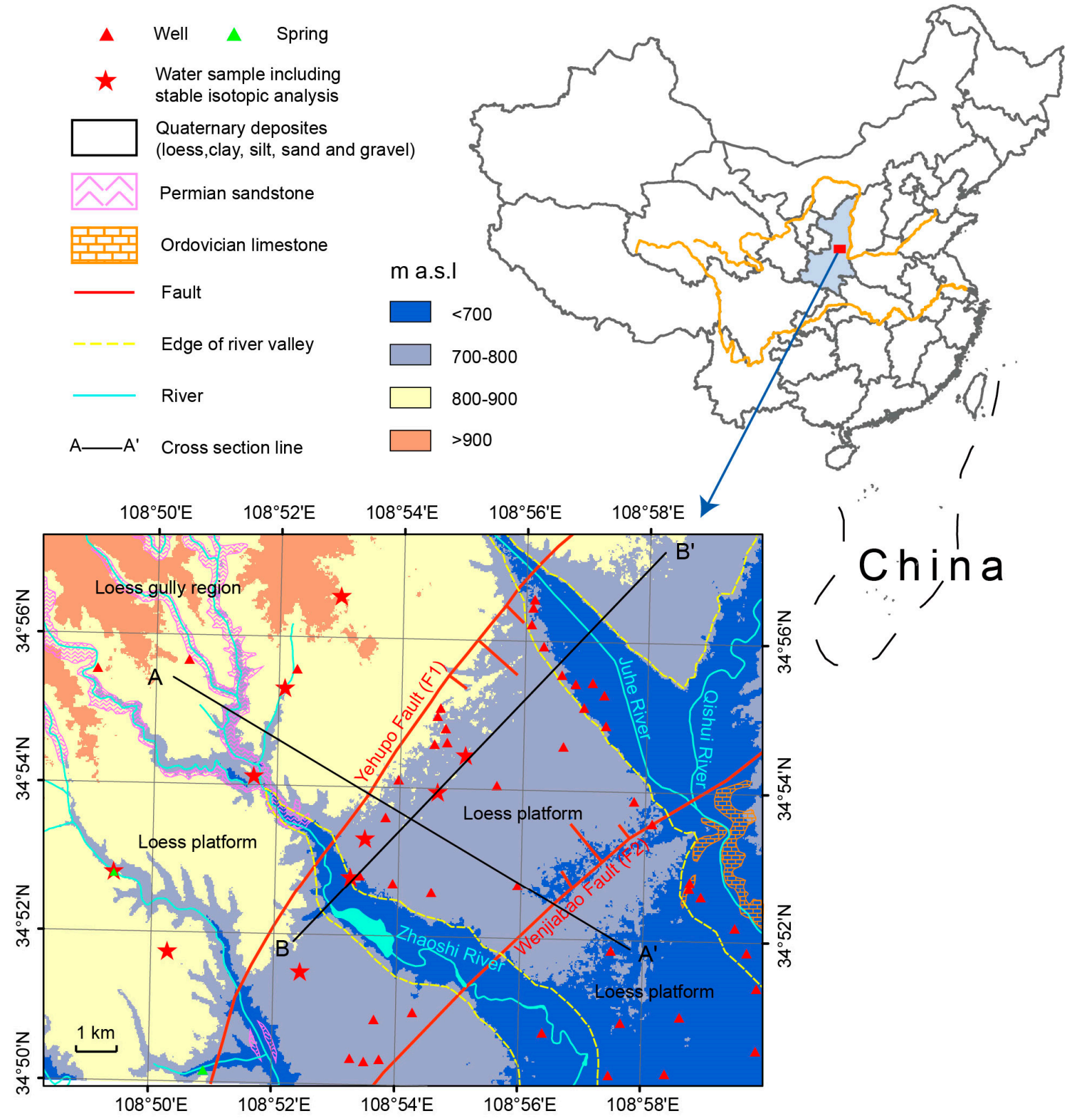

Figure 1. Map showing the location of the study area.

\section{Geology and Hydrogeology}

The oldest rocks are Ordovician limestones, which are distributed evenly across the region. The thick Permian sandstones are distributed in the northwest of Wenjiabao Fault (F2) and underlain conformably by the Ordovician stratigraphy. Quaternary sediments are widespread in the study area and include Holocene sands and gravels and Pleistocene loess deposits. The geological structure is relatively complex in the study area where faults and folds are well developed. The major faults are the Yehupo (F1) and Wenjiabao (F2) faults, and the major folds are Xiaowangzui anticline and Xiaoqiu syncline [22].

Three aquifers are present in the study area, and the groundwater is classified into three types. The first is Quaternary unconsolidated formation pore water, which is contained in the sand gravel aquifer and loess aquifer. Although loess is wide spread and thick in the area, loess rarely contains 
water. The loess aquifer only distributes to the north of the F1 fault and has a low water yield capacity. Currently, the sand gravel aquifer is the most exploited aquifer of this area. Cross-section A-A' (Figure 2) shows that the Permian units have an upward dislocation in the north of the F1 fault and are completely absent to the south of the F2 fault. Offset on the fault makes the middle area subside and accommodate sand and gravel deposition. At the hanging wall of each fault, the sand and gravel unit is relative thin or even absent. Thus, the groundwater distributed between F1 and F2 is abundant with a single well yield ranging from $30-180 \mathrm{~m}^{3} / \mathrm{d}$. South of F2, groundwater is somewhat abundant with the single well yield ranging from $10-30 \mathrm{~m}^{3} / \mathrm{d}$. Water is relatively scarce north of F1 ranging from $5-10 \mathrm{~m}^{3} / \mathrm{d}$. The second aquifer contains water in a clastic rock fissure, which is primarily located north of F2 and has a single well yield between 100-300 $\mathrm{m}^{3} / \mathrm{d}$ or more than $300 \mathrm{~m}^{3} / \mathrm{d}[22,23]$. Fissures and karsts in the Ordovician limestones form the third aquifer. The water yield capacity in this aquifer is generally good but is less exploited because of its high construction cost. In addition, for Quaternary pore water, as the sand gravel aquifer is composed of alternating clay, fine sand, and gravel layers, groundwater exists as confined water. The only unconfined aquifer is in the Juhe River valley (Figure 2).

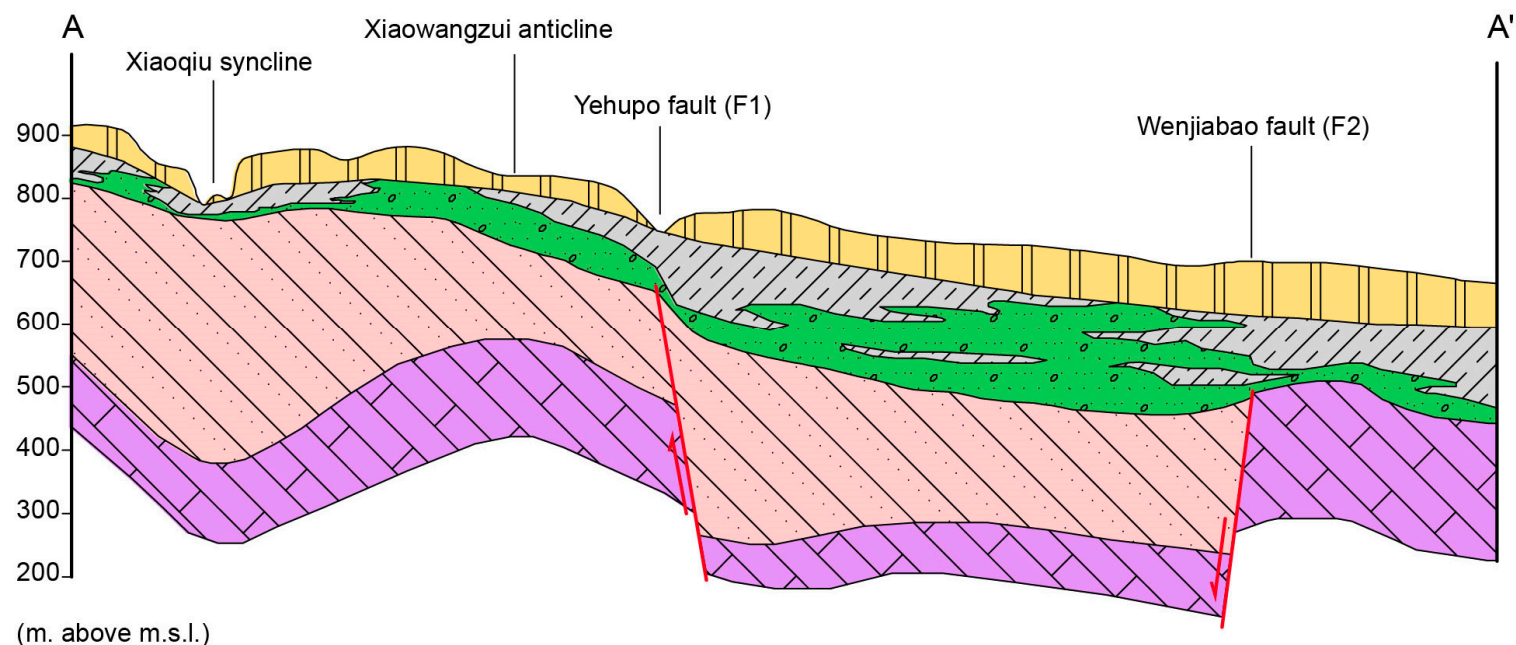

(m. above m.s.l.)

(a)

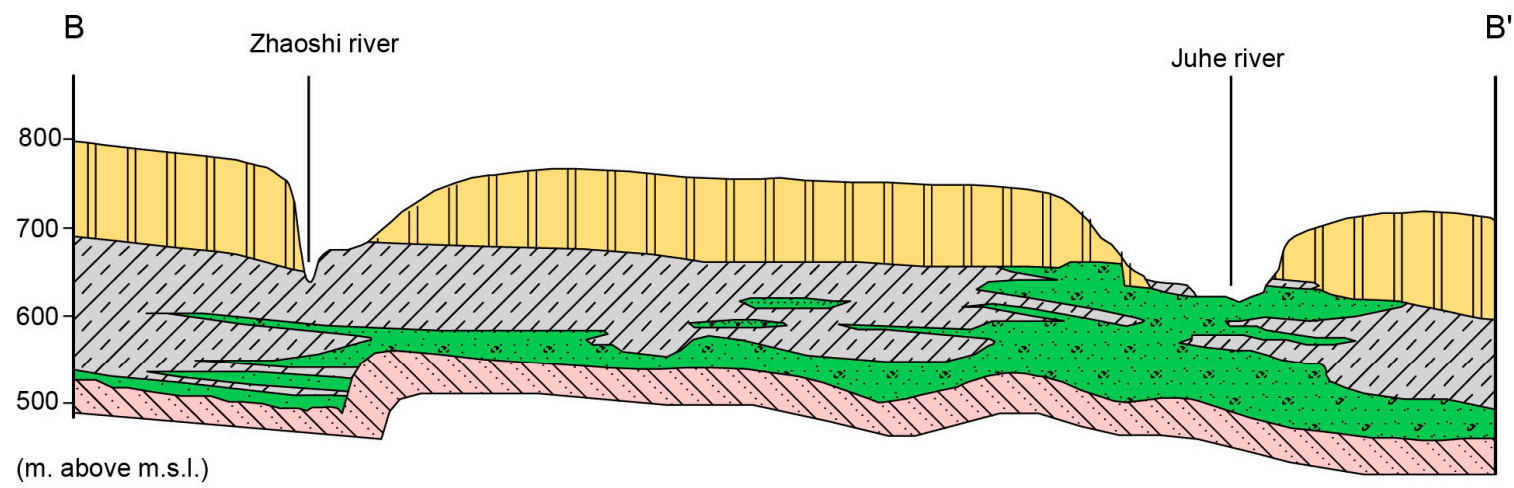

(m. above m.s.l.)

Legend

Loess of Quaternary

Sandstone of Permian
Clay or silt of Quaternary

Limestone of Ordovician

(b)
$A^{\prime}$ 


\section{Methodology}

\subsection{Sampling and Analysis}

The present study utilizes data collected from July to September 2014. Groundwater levels were measured in the monitoring wells to obtain the hydraulic head pattern and determine flow directions under natural conditions. Simultaneously, a total of 58 groundwater samples were collected from the Quaternary aquifer via two springs and 56 pump wells (Figure 1). The well depth ranged from 15-380 m, and screen of all wells was located in the Quaternary aquifer. Samples were collected in plastic bottles, which were rinsed three times with the water before sampling. In situ water temperature and $\mathrm{pH}$ were measured by alcohol thermometer and portable $\mathrm{pH}$ meter (CT-6023), respectively. Major ions $\left(\mathrm{Na}^{+}, \mathrm{K}^{+}, \mathrm{Ca}^{2+}, \mathrm{Mg}^{2+}, \mathrm{Cl}^{-}, \mathrm{SO}_{4}{ }^{2-}\right.$, and $\left.\mathrm{HCO}_{3}{ }^{-}\right), \mathrm{F}^{-}, \mathrm{NH}_{4}{ }^{+}, \mathrm{NO}_{3}{ }^{-}, \mathrm{NO}_{2}{ }^{-}$, chemical oxygen demand (COD), total dissolved solids (TDS), and total hardness (TH) were analyzed in the laboratory at the Shaanxi Bureau of Geology and Mineral by the standard methods of the Ministry of Health of People's Republic of China (PRC) and Standardization Administration of PRC [24]. Among these analyzed indices, $\mathrm{Na}^{+}, \mathrm{K}^{+}, \mathrm{Ca}^{2+}$, and $\mathrm{Mg}^{2+}$ were analyzed using flame atomic absorption spectrometry, $\mathrm{HCO}_{3}{ }^{-}$was measured using hydrochloric acid titrimetric method, $\mathrm{NH}_{4}-\mathrm{N}$ and $\mathrm{NO}_{2}-\mathrm{N}$ were determined by spectrophotometry, $\mathrm{NO}_{3}-\mathrm{N}, \mathrm{SO}_{4}{ }^{2-}, \mathrm{Cl}^{-}$, and $\mathrm{F}^{-}$were measured by ion chromatography, COD was measured by potassium dichromate, and TDS was dried at $180{ }^{\circ} \mathrm{C}$ and then weighed using an analytical balance. Each sample passed an accuracy check via charge balance analysis $\left(\sum\right.$ cation $-\sum$ abion $) /\left(\sum\right.$ cation $+\sum$ anion $) \leq \pm 5 \%$. The results, less than $1 \%$, confirm the reliability of the analysis results.

To analyze the impacts of the fault on groundwater chemistry, ten groundwater samples were collected for analysis of stable hydrogen and oxygen isotopes $\left({ }^{2} \mathrm{H}\right.$ and $\left.{ }^{18} \mathrm{O}\right)$ (Figure 1). The analyses were undertaken in the Shaanxi Entry-exit Inspection and Quarantine Bureau by using $\mathrm{CO}_{2}$ equilibrium method for ${ }^{18} \mathrm{O}$ analysis and zinc reduction method for ${ }^{2} \mathrm{H}$ analysis.

\subsection{Hierarchical Cluster Analysis}

Cluster analysis refers to a multivariate statistical classification method that groups similar observations $[25,26]$. Hierarchical cluster analysis (HCA), which successively joins the most similar observations, is widely used in hydrochemical analyses to identify different chemical characteristics [6,27-29]. In this study, HCA was applied using Euclidian distance with Ward's linkage method for computing cluster distance. Observations classified using this method are more correct than single linkage, complete linkage, and average linkage methods [6]. Ward's method adopts the nearest-neighbor chain algorithm to find the optimal pair of clusters for merge clustering, which generates the most distinct hydrogeochemical signature clusters for water samples. The software Statistical Package for Social Sciences (SPSS) was used to carry out the analysis.

\subsection{Hydrochemical Processes}

Ionic concentration changes were calculated in order to better understand the hydrochemical processes that take place in the study area. $\mathrm{Na}^{+} / \mathrm{Cl}^{-}, \mathrm{Na}^{+} / \mathrm{TZ}^{+}, \mathrm{Ca}^{2+} / \mathrm{Mg}^{2+}$, and $\mathrm{Ca}^{2+}+\mathrm{Mg}^{2+} /\left(\mathrm{HCO}_{3}{ }^{-}+\mathrm{SO}_{4}{ }^{2-}\right)$ molar ratios combined with the mineral saturation indices calculated by PHREEQC (Version 2) [30] were used to determine the sources of anions and cations in the groundwater.

\subsection{Stable Isotopic Analysis}

Stable isotopes are commonly used in order to study the origin and chemical evolution of groundwater [31-33]. The deuterium excess $\left(\mathrm{d}-\right.$ excess $\left.=\delta \mathrm{D}-8 \times \delta^{18} \mathrm{O}\right)$ is usually used to describe the evaporation influence on water bodies compared to that of precipitation [31]. Besides, the deviation from a slope of 8 on a plot of $\delta \mathrm{D}$ versus $\delta^{18} \mathrm{O}$ can also indicate mixing between different water groups or water-rock interactions [34,35]. 


\section{Result and Discussion}

\subsection{Hydraulic Head Patterns and Flow Directions}

To determine the effects of faulting on the flow pattern, groundwater equipotential lines were drawn separately for the three sectors separated by the faults (Figure 3). The water flow is the same on both side of the two faults, and equipotential lines correspond across F1 and F2. As a result, the faults are normal tension faults, have hydraulic connection with each other, and have a great capacity to accommodate groundwater flow. Spatial distribution of groundwater depth is also shown in Figure 3, which has a similar trend with the variation of altitudes. The average depth to groundwater table is $92.5 \mathrm{~m}$ whereas minimum and maximum values are $15 \mathrm{~m}$ and $165 \mathrm{~m}$, respectively. The shallow groundwater system prevails mainly in regions with low altitudes, especially in valley regions which have depth ranges between 15-50 m and occupy $15.7 \%$ of total area. Areas with depth ranges between 100-140 m occupy $41.7 \%$ of the total area and are distributed north of the F1 fault and occupy half the area between F1 and F2. Therefore, by considering depth to groundwater, the valley regions are more vulnerable to anthropogenic influence.

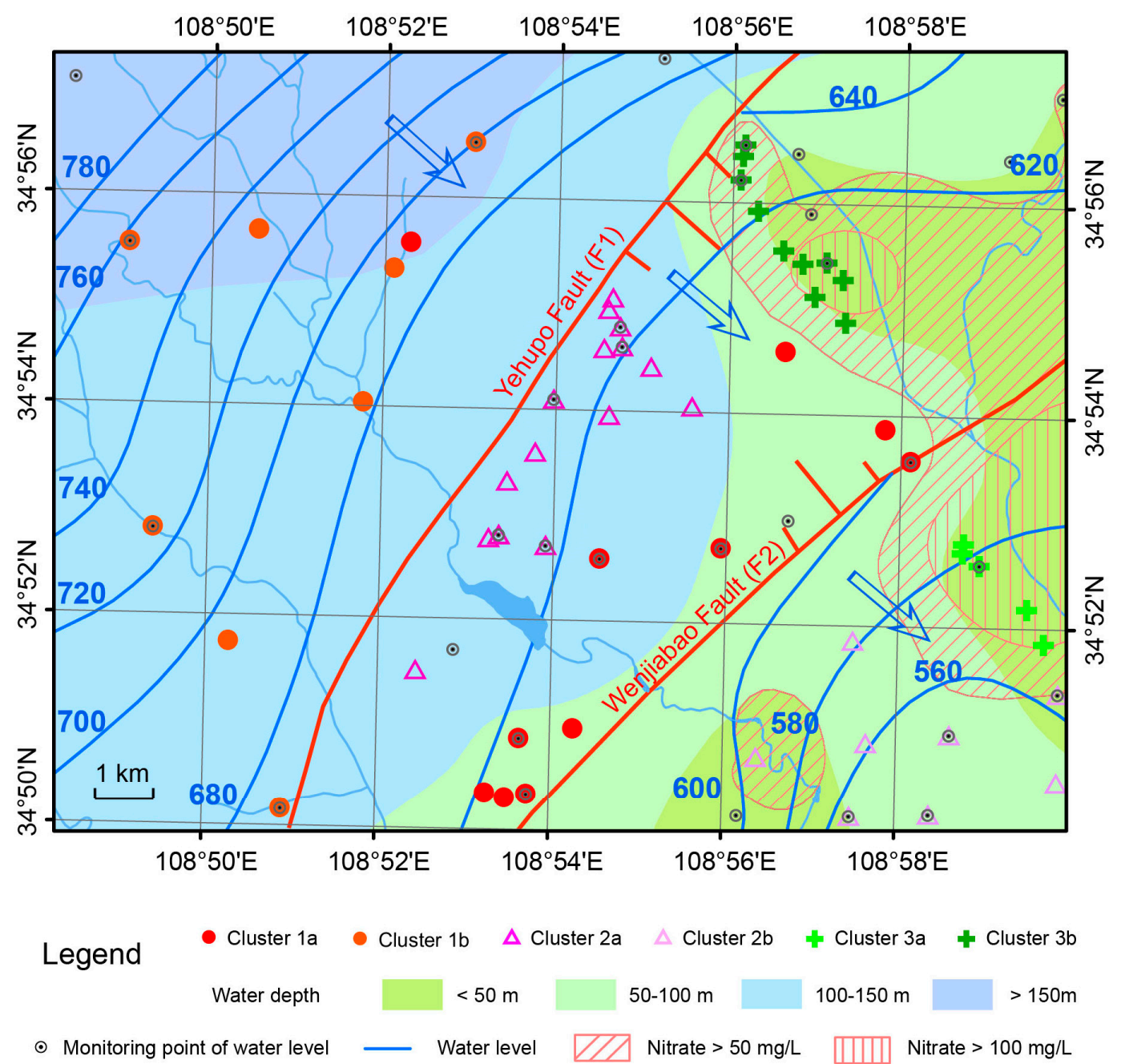

Figure 3. Map showing the hydraulic head pattern, groundwater flow direction, groundwater depth, location of monitoring wells, areas where nitrate exceeds the World Health Organization (WHO) guideline value, and distribution of all sub-clusters. 


\subsection{Hydrochemical Characteristics}

Table 1 shows major groundwater components in the study area with minimum, maximum, average, and standard World Health Organization (WHO) values. Groundwater is neutral to mildly alkaline with a $\mathrm{pH}$ ranging from 6.9 to 7.5 with little variance. TDS ranges from 303.9 to $1033.2 \mathrm{mg} / \mathrm{L}$ (mean: 528.1). Only three samples contain TDS above the permissible limit defined by WHO drinking standards. Bicarbonate $\left(\mathrm{HCO}_{3}{ }^{-}\right)$concentration varies from 268.5 to $585.8 \mathrm{mg} / \mathrm{L}$ (mean: 406.1) and 100\% of samples exceed the WHO guideline value. The mean chloride and sulfate concentrations are 24.1 and $68.9 \mathrm{mg} / \mathrm{L}$, respectively, and only four samples contain sulfate above WHO standards. The mean $\mathrm{Na}^{+}+\mathrm{K}^{+}$concentration is $92.1 \mathrm{mg} / \mathrm{L}$, and only two samples contain $\mathrm{Na}^{+}+\mathrm{K}^{+}$concentrations above the WHO guideline. Calcium concentration is greater than magnesium concentration and ranges from 14.7 to $194.0 \mathrm{mg} / \mathrm{L}$. High fluoride concentration occurs in local areas, and $8 \%$ of the samples exceed the WHO limit; these samples are mainly in the northwestern part of the study area. Nitrate concentration varies between 0.5 and $173.3 \mathrm{mg} / \mathrm{L}$, and $26.3 \%$ of samples exceed the nitrate concentration limit. Figure 3 shows that all the shallow groundwater areas were polluted by $\mathrm{NO}_{3}{ }^{-}$, which is dangerous to human health and to the environment. Studies have shown the high $\mathrm{NO}_{3}{ }^{-}$was probably from agricultural input $[9,10]$. However, variety fertilizers not only provide nitrate into groundwater but also provide calcium, magnesium, chloride, phosphorus, and potassium [36], which may cause a significant change in groundwater geochemistry.

Table 1. Statistical summary of hydrochemical components in the study area.

\begin{tabular}{ccccc}
\hline Index & Mean & Min & Max & Acceptable Limits (WHO 2004) \\
\hline $\mathrm{pH}$ & 7.5 & 6.9 & 7.9 & $6.5-9.2$ \\
Total Dissolved Solids $(\mathrm{mg} / \mathrm{L})$ & 528.1 & 303.9 & 1033.2 & 1000 \\
$\mathrm{Na}^{+}+\mathrm{K}^{+}(\mathrm{mg} / \mathrm{L})$ & 92.1 & 28.7 & 227.7 & 200 \\
$\mathrm{Ca}^{2+}(\mathrm{mg} / \mathrm{L})$ & 56.8 & 14.7 & 194.0 & 200 \\
$\mathrm{Mg}^{2+}(\mathrm{mg} / \mathrm{L})$ & 31.0 & 10.7 & 66.0 & 150 \\
$\mathrm{Cl}^{-}(\mathrm{mg} / \mathrm{L})$ & 24.1 & 5.4 & 166.5 & 250 \\
$\mathrm{SO}_{4}{ }^{-}(\mathrm{mg} / \mathrm{L})$ & 68.9 & 7.1 & 293.6 & 250 \\
$\mathrm{HCO}_{3}{ }^{-}(\mathrm{mg} / \mathrm{L})$ & 406.1 & 268.5 & 585.8 & 240 \\
$\mathrm{~F}^{-}(\mathrm{mg} / \mathrm{L})$ & 0.5 & 0.1 & 1.5 & 1.5 \\
$\mathrm{NO}_{3}{ }^{-}(\mathrm{mg} / \mathrm{L})$ & 37.1 & 0.5 & 173.3 & 50 \\
$\mathrm{PO}_{4}{ }^{-}(\mathrm{mg} / \mathrm{L})$ & 0 & 0 & 0.2 & - \\
\hline
\end{tabular}

\subsection{Hierarchical Cluster Analysis}

Hierarchical cluster analysis was applied to the set of nine variables, specifically: total hardness (TH), $\mathrm{pH}, \mathrm{Na}^{+}, \mathrm{Ca}^{2+}, \mathrm{Mg}^{2+}, \mathrm{Cl}^{-}, \mathrm{SO}_{4}{ }^{2+}, \mathrm{HCO}_{3}{ }^{-}, \mathrm{NO}_{3}{ }^{-}, \mathrm{F}^{-}$, and $\mathrm{PO}_{4}{ }^{3-}$. Three clusters were identified from 58 wells (Figure 4). The spatial distribution of the clusters is presented in Figure 3. Sampling records from the same region are generally assigned to the same cluster during HCA. Cluster 1 is dominated by a mixed-type including 19 groundwater samples, which account for $32.8 \%$ of the total samples and have no distinctive characteristics in regard to the evaluated ions. Cluster 1 is further sub-divided in sub-Clusters $1 \mathrm{a}$ and $1 \mathrm{~b}$ that are distributed on either side of the F1 fault. Cluster 2 contains $41.4 \%$ of all groundwater and has a $\mathrm{Na}-\mathrm{HCO}_{3}$ water type. Cluster 2 is further sub-divided into sub-Clusters $2 \mathrm{a}$ and $2 \mathrm{~b}$, which are located relatively far away from each other. Groundwater samples in Cluster 3 have a $\mathrm{Ca}-\mathrm{HCO}_{3}$ and $\mathrm{Ca}-\mathrm{SO}_{4}$ water type, and account for $25.8 \%$ of the total samples. Cluster 3 samples are located mainly in the Juhe River valley. Cluster 3 also has two sub-clusters, $3 \mathrm{a}$ and $3 \mathrm{~b}$, which are located in the midstream and downstream regions, respectively. The $\mathrm{Ca}-\mathrm{SO}_{4}$ water type is found in sub-cluster $3 b$.

Cluster distribution shows some correlation with the physiognomy and geology tectonics, which may cause different hydrochemical processes. 


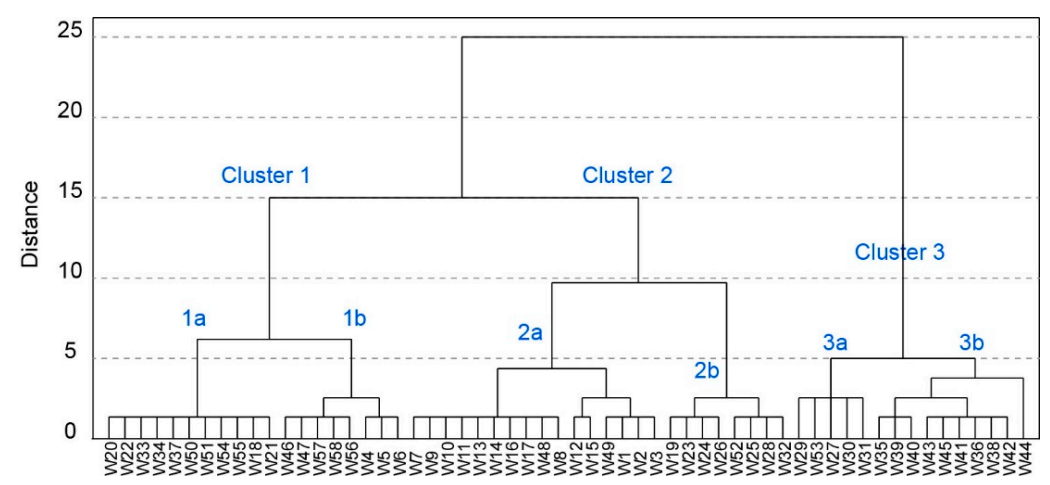

Figure 4. Dendrogram for the Hierarchical Cluster Analysis showing the three identified clusters and sub-clusters.

\subsection{Hydrochemical Processes}

The hydrogeochemical processes and aquifer mechanism are identified with the help of various graphical plots, which are discussed below.

Chemical components and formation of groundwater are controlled by the geological environment, which is a result of the long geological evolution processes. To some extent, major ions constituting the total dissolved solids (TDS) reflect the hydrogeochemical processes that take place in the aquifer system [37]. In Figure 5, as the TDS increase, all ion concentrations increase in varying degrees. $\mathrm{Ca}^{2+}$ and $\mathrm{Na}^{+}$provide a larger contribution than does $\mathrm{Mg}^{2+}$ to cations, and $\mathrm{HCO}_{3}{ }^{-}$provides a significant contribution to anions. In addition, $\mathrm{Ca}^{2+}$ and $\mathrm{Na}^{+}$show a counter-balance and $\mathrm{HCO}_{3}{ }^{-}$ has a decreasing trend when TDS range from 600 to $1000 \mathrm{mg} / \mathrm{L}$. From the relationship between TDS and the major ions, it is preliminarily concluded that the dissolution of minerals containing $\mathrm{Ca}^{2+}$, $\mathrm{Na}^{+}$, and $\mathrm{HCO}_{3}{ }^{-}$make up the majority of the water-rock interaction. These minerals may be calcite, dolomite, or albite. Secondly, $\mathrm{SO}_{4}{ }^{2-}$ and $\mathrm{Cl}^{-}$may be from gypsum and halite dissolution. Meanwhile ion exchange processes may exist between $\mathrm{Ca}^{2+}$ and $\mathrm{Na}^{+}$.
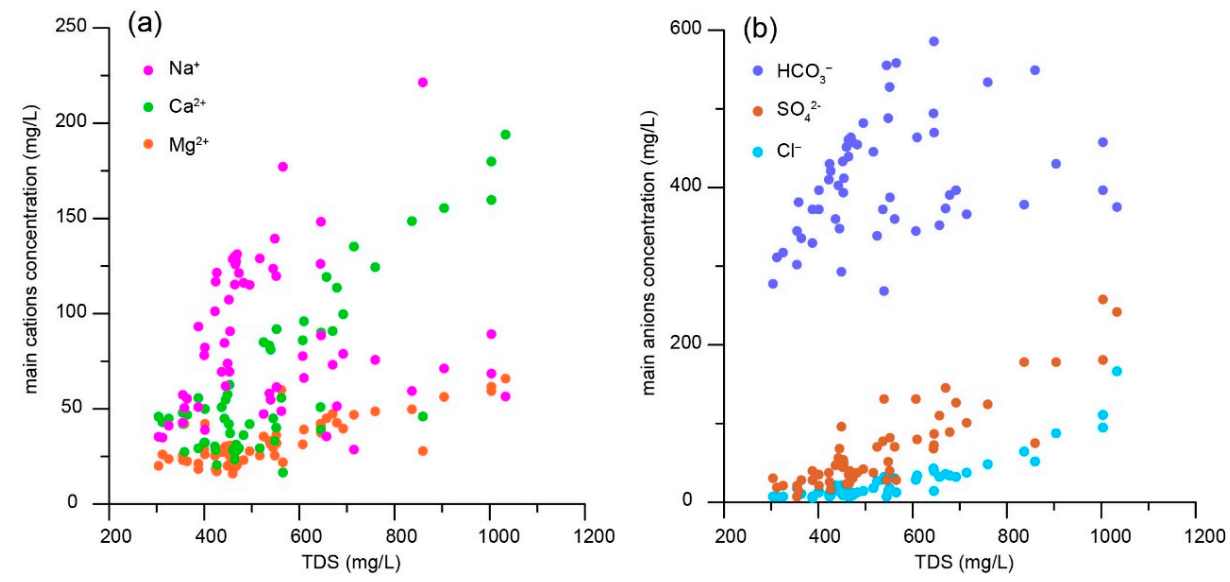

Figure 5. Scatter plots for (a) the main cations and (b) the main anions versus TDS.

\subsubsection{Silicate Weathering}

Silicate weathering is one of the key geochemical processes controlling the major ionic chemistry of groundwater, especially in hard rock aquifers [38]. Sodium, the most abundant cation, mainly comes from halite and silicate rocks. If halite dissolution is responsible for sodium concentration, the $\mathrm{Na} / \mathrm{Cl}$ molar ratio should be approximately equal to one, whereas a ratio greater than one is commonly interpreted as Na released from a reaction during silicate weathering [39,40]. Samples lie 
above the $\mathrm{Na} / \mathrm{Cl}$ 1:1 line, suggesting the sodium can be possibly attributed to silicate weathering (Figure 6a). If silicate weathering is the source of the sodium, water samples should have $\mathrm{HCO}_{3}{ }^{-}$as the most abundant anion [41,42]. In the present study, $\mathrm{HCO}_{3}{ }^{-}$is the dominant anion. The silicate weathering process can be examined by estimating the ratio of $\mathrm{Na}^{+}$to total cations ( $\mathrm{TZ}^{+}$) (Figure 6b) [43]. Groundwater samples from the cluster 3 are above $0.33 \mathrm{TZ}^{+}$, indicating that there is less silicate weathering. Samples from cluster 2 fall below the 1:2 line, indicating an abundance of silicate weathering. Cluster 1 is somewhat scattered, sub-cluster 1a shows relatively little silicate weathering while sub-cluster $1 \mathrm{~b}$ shows some silicate weathering.
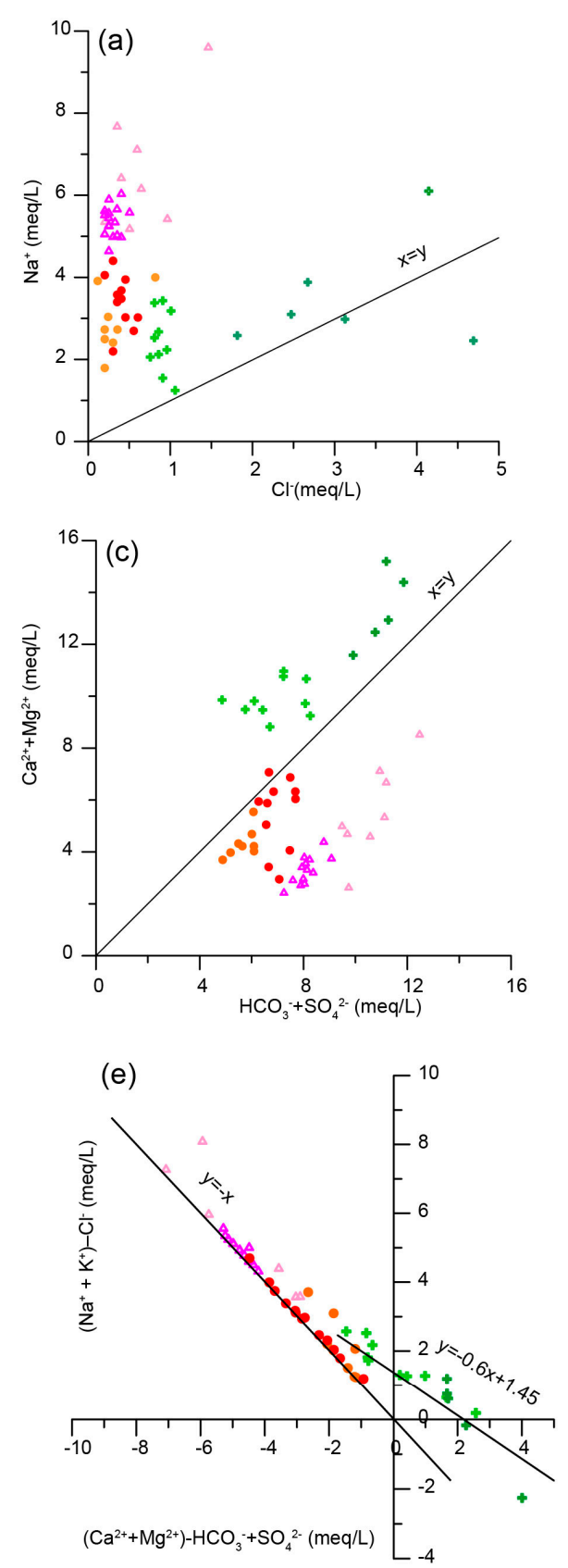

Legend - cluster 1a - cluster 2a $\quad \Delta \quad$ cluster 2a
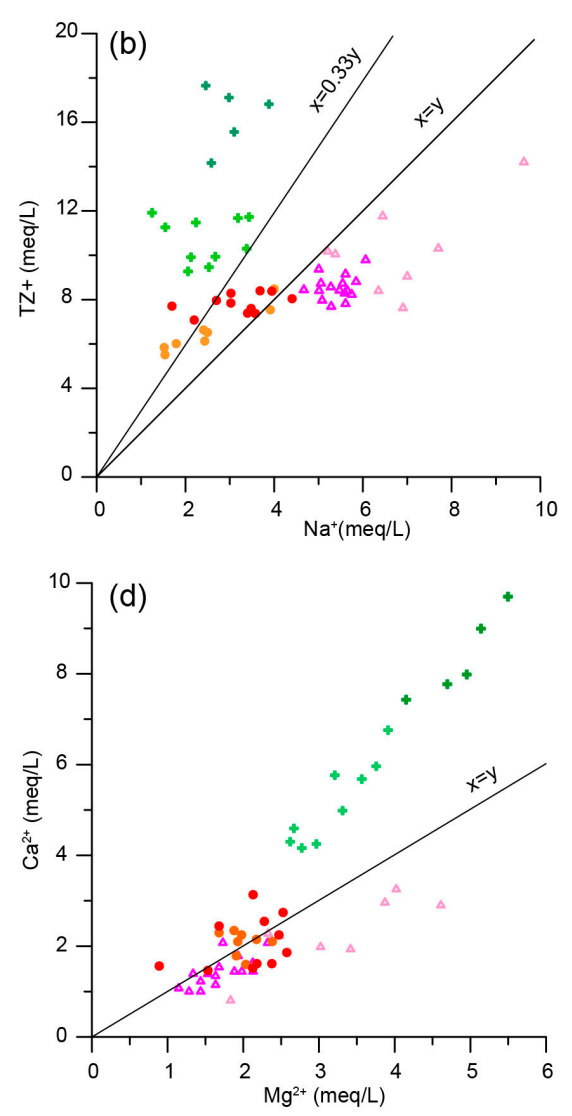

(f)

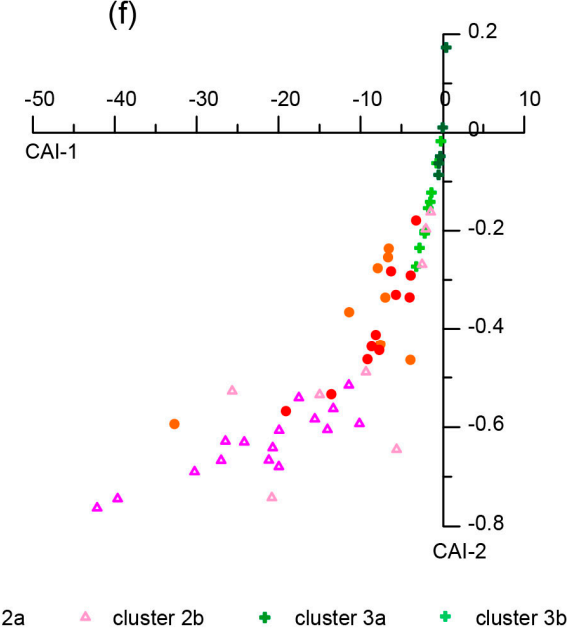

Figure 6. Plots showing (a) $\mathrm{Na}^{+}$versus $\mathrm{Cl}^{-},(\mathbf{b}) \mathrm{Na}^{+}$versus $\mathrm{TZ}^{+},(\mathbf{c})\left(\mathrm{Ca}^{2+}+\mathrm{Mg}^{2+}\right)$ and $\left(\mathrm{HCO}_{3}{ }^{-}+\mathrm{SO}_{4}{ }^{2-}\right)$, (d) $\mathrm{Ca}^{2+}$ versus $\mathrm{Mg}^{2+}$, (e) $\left(\mathrm{Ca}^{2+}+\mathrm{Mg}^{2+}\right)-\left(\mathrm{HCO}_{3}{ }^{-}+\mathrm{SO}_{4}{ }^{2-}\right)$ and $\left(\mathrm{Na}^{+}+\mathrm{K}^{+}\right)-\mathrm{Cl}^{-}$, and (f) $\mathrm{CAI} 1$ versus CAI 2. 
Otherwise, in the $\mathrm{Ca}^{2+}+\mathrm{Mg}^{2+}$ versus $\mathrm{SO}_{4}{ }^{2-}+\mathrm{HCO}_{3}{ }^{-}$scatter diagram (Figure $6 \mathrm{c}$ ), sample points fall along the equiline $\left(\mathrm{Ca}^{2+}+\mathrm{Mg}^{2+}=\mathrm{SO}_{4}{ }^{2-}+\mathrm{HCO}_{3}{ }^{-}\right)$, suggesting that these ions come from weathering of carbonates and silicates $[5,44,45]$. About $67 \%$ samples of the cluster 3 are on the $\mathrm{Ca}^{2+}+\mathrm{Mg}^{2+}$ side vs. the $\mathrm{SO}_{4}{ }^{2-}+\mathrm{HCO}_{3}{ }^{-}$side, indicating carbonate weathering is the dominant hydrogeochemical process. Cluster 1 is distributed near the 1:1 line and cluster 2 is relatively far from the 1:1 line, indicating weathering of both carbonates and silicates and dominant silicates weathering, respectively, which is consistent with the aforementioned conclusion. In addition, cluster $2 \mathrm{~b}$ shows more silicate weathering than cluster $2 \mathrm{a}$.

\subsubsection{Carbonate Weathering and Dissolution}

Saturation indices (SI) for gypsum, dolomite, and calcite are calculated using PHREEQC. By using the saturation index approach, it is possible to predict the reactive mineralogy of the subsurface from groundwater data without collecting and analyzing mineral samples [45]. The SI values for calcite and dolomite for all groundwater samples are greater than zero (Figure 7), indicating oversaturation and precipitation of these carbonate minerals. In contrast, gypsum SI values for all groundwater samples are less than zero, indicating the groundwater is unsaturated. Therefore, calcite and dolomite may be the primary carbonate minerals in the study area.

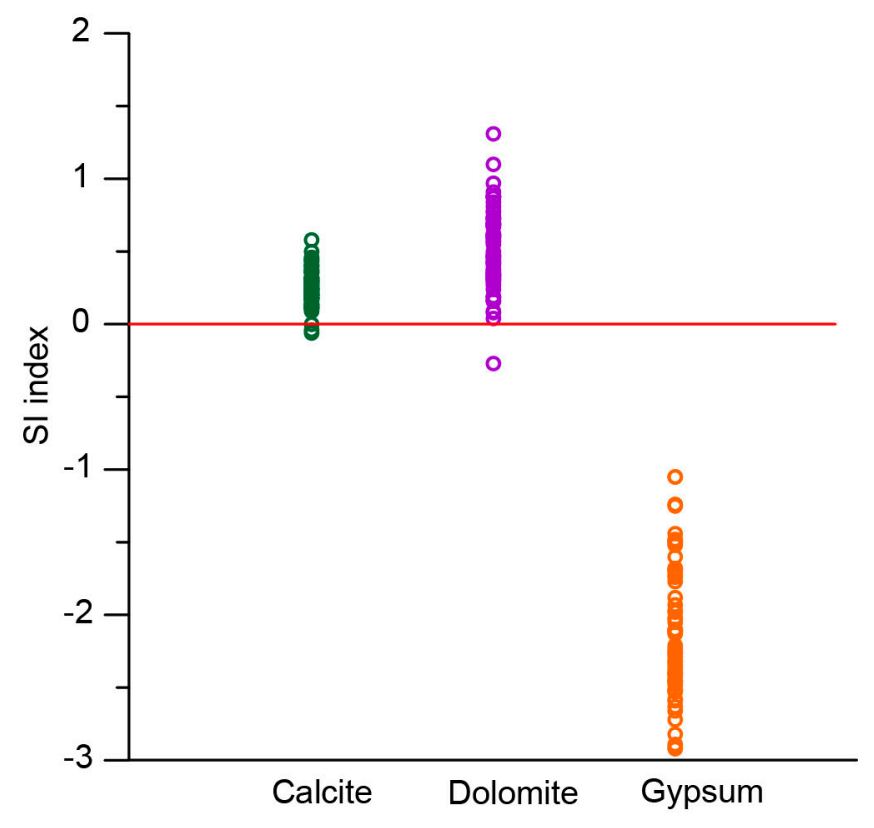

Figure 7. Saturation indices for calcite, dolomite, and gypsum.

The $\mathrm{Ca}^{2+} / \mathrm{Mg}^{2+}$ molar ratios of groundwater samples depict the dissolution of calcite and dolomite that present in the weathered zone (Figure 6d) [5]. If the ratio $\mathrm{Ca}^{2+} / \mathrm{Mg}^{2+}=1$, dissolution of dolomite should occur, whereas a ratio $>1$ is indicative of calcite dissolution $[29,46]$. Samples from clusters 1 and 2 are distributed near the $\mathrm{Ca} / \mathrm{Mg}=1$ line, indicating the dissolution of dolomite. Cluster 3 samples show ratios greater than 1 , indicating that calcite dissolution is dominant.

\subsubsection{Ion Exchange}

Ion exchange reactions with clay material is responsible for the concentration of ions in groundwater [5]. The direct ion exchange and reverse ion exchange can be expressed as Equations (1) and (2), respectively:

$$
\begin{aligned}
& 2 \mathrm{Na}^{+}+\mathrm{CaX}_{2}=2 \mathrm{NaX}+\mathrm{Ca}^{2+} \\
& \mathrm{Ca}^{2+}+2 \mathrm{NaX}=\mathrm{CaX}_{2}+2 \mathrm{Na}^{+}
\end{aligned}
$$


where $\mathrm{X}$ indicates the soil exchanger [47]. An excess of $\mathrm{Ca}^{2+}$ or $\mathrm{Mg}^{2+}$ in groundwater may be due to the exchange of $\mathrm{Na}^{+}$in the water by $\mathrm{Ca}^{2+}$ or $\mathrm{Mg}^{2+}$ in clay material, while an excess of $\mathrm{Na}^{+}$may be due to the exchange of $\mathrm{Ca}^{2+}$ or $\mathrm{Mg}^{2+}$ in the water by $\mathrm{Na}^{+}$in clay material [48].

In order to assess the possible role of ion exchange in the hydrochemistry of groundwater, $\left(\mathrm{Ca}^{2+}+\mathrm{Mg}^{2+}\right)-\left(\mathrm{HCO}_{3}{ }^{-}+\mathrm{SO}_{4}{ }^{2-}\right)$ in meq/L was plotted against $\left(\mathrm{Na}^{+}+\mathrm{K}^{+}\right)-\mathrm{Cl}^{-}$in meq/L. The $\left(\mathrm{Ca}^{2+}+\mathrm{Mg}^{2+}\right)-\left(\mathrm{HCO}_{3}{ }^{-}+\mathrm{SO}_{4}{ }^{2-}\right)$ equation means that the cations $\mathrm{Ca}$ and $\mathrm{Mg}$ were corrected by omitting the influences by other processes (e.g., carbonate or silicate weathering), whereas the $\left(\mathrm{Na}^{+}+\mathrm{K}^{+}\right)-\mathrm{Cl}^{-}$equation means that the cations $\mathrm{K}$ and $\mathrm{Na}$ were from sources other than their respective chlorides [49]. If ion exchange is the dominant process in the system, the samples should form a line with a slope of $-1[16,20,42,49]$. Figure 6e shows that cluster 1 and cluster 2 samples have a slope of -1 , indicating cation exchange influences the groundwater chemistry of these samples, and cluster 3 has a slope of -0.6 , indicating that cation exchange shows less influence on the water chemistry in cluster 3 than it does in the other clusters.

Chloro alkaline indices (CAI) [37,49], calculated using Equations (3) and (4), were further used to identify the specific ion exchange between the groundwater and its host environment.

$$
\begin{gathered}
\mathrm{CAI}-1=\frac{\mathrm{Cl}^{-}-\left(\mathrm{Na}^{+}+\mathrm{K}^{+}\right)}{\mathrm{Cl}^{-}} \\
\mathrm{CAI}-2=\frac{\mathrm{Cl}^{-}-\left(\mathrm{Na}^{+}+\mathrm{K}^{+}\right)}{\mathrm{SO}_{4}^{2-}+\mathrm{HCO}_{3}^{-}+\mathrm{CO}_{3}^{2-}+\mathrm{NO}_{3}^{-}}
\end{gathered}
$$

All values are expressed in meq/L. When there is an exchange between $\mathrm{Na}^{+}$or $\mathrm{K}^{+}$in the water with $\mathrm{Mg}^{2+}$ or $\mathrm{Ca}^{2+}$ in rock, this indicates a direct ion exchange. $\mathrm{Na}^{+}$or $\mathrm{K}^{+}$will decrease in water and both the above indices will be positive. In contrast, the reverse ion exchange will produce negative indices [37]. Figure 6f shows that most of the samples indicate negative values for both indices, suggesting reverse ion exchange in the system. Only cluster $3 \mathrm{~b}$ shows positive values in individual samples.

\subsection{Hydrochemical Difference among All Clusters}

The varying lithology of the bedrock and associated soil forms different types of groundwater. Moreover, tectonic structures, especially faults, control the spatial distribution of strata and geomorphology, which is related to the different types of groundwater [16].

Owing to the impact of the geological structure, aquifers may not be continuous in the same unit. The similar aquifers on both sides of the F2 fault produce the similar clusters 1a and 1b, which are both dominated by carbonate and silicate weathering. However, silicates weathering has more influence in cluster $1 \mathrm{~b}$ than in cluster1a. In addition, a loess aquifer exists north of the F1 fault, but south of the F1 fault, the loess is permeable but does not contain water. Thus, north of the F2 fault there could be some mixing between water from the sand gravels aquifer and the loess aquifer, which could explain the difference between $1 \mathrm{a}$ and $1 \mathrm{~b}$.

Cluster 3 shows a distinctive difference from cluster 1 and 2 in molar ratio graphs. The reasons can be concluded as follows. Firstly, the Ordovician carbonates exposed in the valley region result in carbonate weathering being the main hydrochemical process for cluster 3. Secondly, the only unconfined aquifer with shallow water depth makes the valley region more vulnerable to pollution than the other regions. Nitrate contamination from agricultural infiltration has already threatened the water quality in shallow water depth areas, which also influences water chemistry. In addition, cluster $3 \mathrm{~b}$ shows a direct ionic exchange process while cluster $3 \mathrm{a}$ shows reverse ionic exchange progress. Cluster $3 b$ is centered on a populated area, in addition to agriculture, industrial and domestic activities affect the unconfined aquifer, which can produce the differences between clusters $3 \mathrm{a}$ and $3 \mathrm{~b}$. Cluster 2 is distributed in two locations. As the faults connect water, cluster $2 a$ within the same aquifer as cluster 1 should have similar chemical characteristics along the flow path. However, cluster 2a located 
between clusters $1 \mathrm{a}$ and $1 \mathrm{~b}$ is not classified in the same group and shows distinctive water chemical characteristics. Cluster $2 \mathrm{~b}$ is located in the south of $\mathrm{F} 2$ within a different aquifer but is classified in the same group. The rational reason for this is discussed in Section 5.5 .

\subsection{Discussion of Cluster $2 a$}

The value of $\mathrm{d}$-excess is determined by the variability of $\delta \mathrm{D}$ and $\delta^{18} \mathrm{O}$ values. Generally, the variations are correlated primarily with isotope composition of precipitation that changes in elevation, latitude, distance from the coast, and temperature [50]. However, for groundwater, the variation in d-excess is hard to interpret because precipitation is not the only recharge source, and the hydrogeological setting is quite complex. The variations of $\delta \mathrm{D}$ and $\delta^{18} \mathrm{O}$ in groundwater can be caused by a variety of mechanisms [50]: (1) geographic displacement by subsurface, (2) recharge from partially evaporated or polluted surface water bodies, (3) recharge that occurred in past periods of different climate when the isotope composition of precipitation was different from that at present, (4) mixing with different water groups, such as subsurface brines, seawater, or water from other aquifers, (5) interactions with rocks accompanied by an isotope exchange, and (6) evaporation influence on different groundwater depth.

In the sampled area, the possible mechanisms that change $\delta \mathrm{D}$ and $\delta^{18} \mathrm{O}$ are relatively simple. Firstly, as the sampled groundwater has a deep water depth of $>100 \mathrm{~m}$, evaporation has negligible effect on the change in water chemistry. Secondly, as groundwater belongs to the same aquifer system in a small area, there are no differences in both recharge sources, hydrometeorological, and geological conditions. Thus, d-excess is most likely contributed to mechanisms of water-rock interaction and mixing process in the sampled area. Water-rock interaction happens continuously along the groundwater flow path. During the dissolution process of a variety of minerals, rocks release ions and oxygen elements to the groundwater, which result in TDS and $\delta^{18} \mathrm{O}$ enrichment. Generally, TDS and $\delta^{18} \mathrm{O}$ content downstream is higher than that upstream because of accumulation of water-rock interaction. TDS are expected to increase from cluster $1 \mathrm{~b}$ to cluster $2 \mathrm{a}$ to cluster $1 \mathrm{a}$. However, results show the TDS content for cluster 2a is higher than cluster 1a (Figure 8), which is contrary to the evolution laws. In addition, if the high TDS result from more water-rock interaction, $\delta^{18} \mathrm{O}$ should also increase at the same time, which results in low d-excess. However, data analysis shows $\delta^{18} \mathrm{O}$ values are similar in all clusters. The low d-excess value in cluster $2 a$ is not only caused by water-rock interaction along the flow path but also by another reason, which is probably mixing between different water groups.
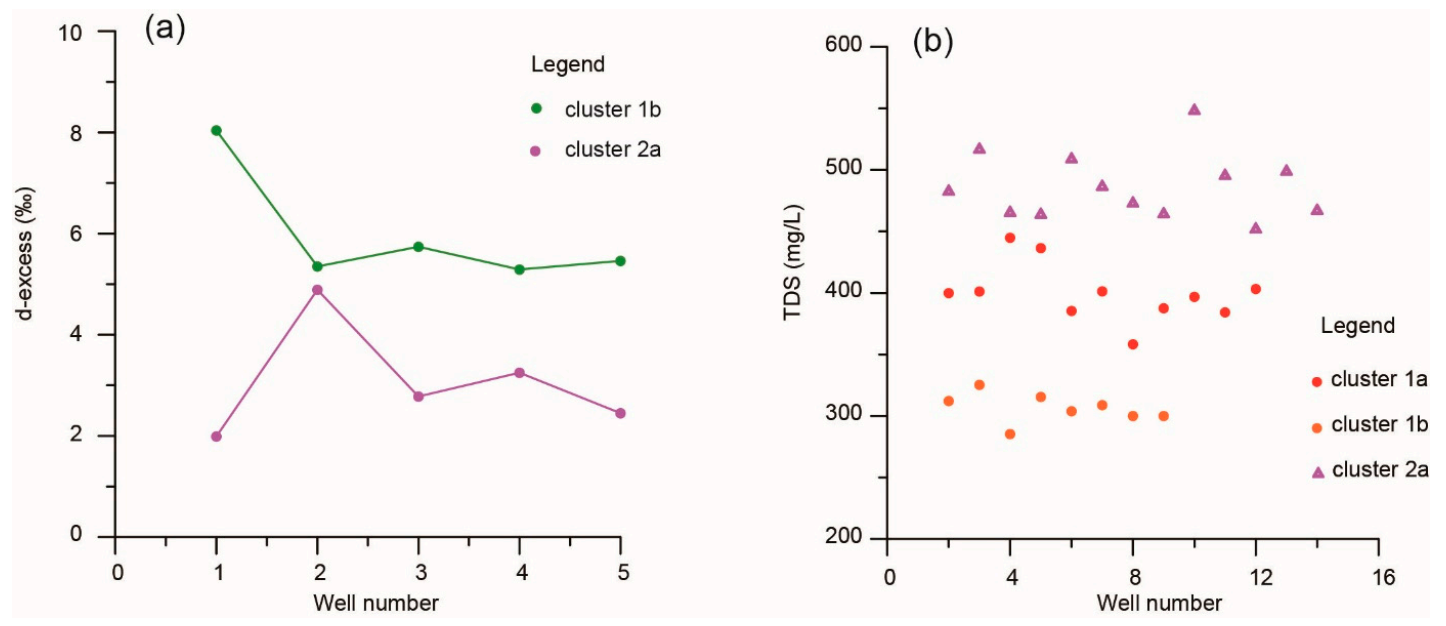

Figure 8. Scatter plot for (a) d-excess of cluster 1a and 2a and (b) TDS of cluster 1a, 1b, and 2a. 
Generally, aquifers of fault tectonics occur in the fracture zone. As the rock in each wall is relatively impermeable and the structure of the fault itself may contain void spaces, fracture zones become good reservoir structures when the recharge conditions are appropriate. In addition, the fracture zone, under the most intense strain, is commonly surrounded by fault breccia. Observation in the well log show fault breccia and fractures near the F1 fault [23], and cluster 2a represents a water zone formed by the F1 fault. Almost all wells in cluster 2a have a depth of $150 \mathrm{~m}$ and intersect the fracture zone. It is possible to cause mixing between Quaternary pore water and clastic rock fissure water during the pumping of these wells. Combined with the evidence of d-excess, the sampled water from cluster $2 a$ indicates mixing between Quaternary pore water and clastic rock fissure water.

\section{Conclusions}

Understanding how the hydrochemistry of groundwater evolves within aquifers along groundwater flow paths is crucial for the management of groundwater resources in semi-arid areas. In the present study, statistical analysis, graphical plots, and isotopic techniques were applied to investigate the hydrochemical characteristics and major factors influencing groundwater evolution. The following conclusions can be reached:

1. Statistical analysis shows that the relative abundance of major cations in the groundwater is $\mathrm{Na}^{+}>\mathrm{Ca}^{2+}>\mathrm{Mg}^{2+}$, whereas the relative abundance of anions is $\mathrm{HCO}_{3}{ }^{-}>\mathrm{SO}_{4}{ }^{2-}>\mathrm{Cl}^{-}$. The groundwater is polluted with $\mathrm{NO}_{3}{ }^{-}$in shallow water depth areas, which is attributed to anthropogenic factors, especially agriculture.

2. Three clusters with different characteristics were identified using HCA in the study area, which is in accordance with the different water types. Clusters 1 and 2 exhibit hydrochemical facies of mixed- $\mathrm{HCO}_{3}$ and $\mathrm{Na}-\mathrm{HCO}_{3}$, respectively. Cluster 3 exhibits mixed facies of $\mathrm{Ca}-\mathrm{HCO}_{3}$ or $\mathrm{Ca}-\mathrm{SO}_{4}$.

3. Hydrochemical processes show the predominance of carbonate and silicate weathering in cluster 1, silicate weathering and ionic exchange in cluster 2, carbonate weathering in cluster 3 , and ionic exchange in all clusters.

4. Geological factors play an important role in groundwater chemistry. The chemistry of samples near the F1 fault is different from that in the other samples in the same aquifer along the flow path, even though F1 is a permeable fault. Oxygen and hydrogen isotopes indicate mixing between Quaternary pore water and clastic rock fissure water causing abnormal groundwater chemistry.

Acknowledgments: The research was supported by the National Natural Science Foundation of China (41572236) and the Fundamental Research Funds for the Central Universities of Chang'an University (310829173306, 310829173701, 310829172202). We also wish to express our gratitude to the reviewers for their constructive comments.

Author Contributions: Hui Qian provided the writing ideas and supervised the study; Xinyan Li conceived the research and wrote the paper; Hui Qian and Yanyan Gao took the water samples and analyzed the data.

Conflicts of Interest: The authors declare no conflict of interest.

\section{References}

1. Li, P.; Tian, R.; Xue, C.; Wu, J. Progress, opportunities, and key fields for groundwater quality research under the impacts of human activities in China with a special focus on western China. Environ. Sci. Pollut. Res. 2017, 24, 13224-13234. [CrossRef] [PubMed]

2. Chen, J.; Wu, H.; Qian, H.; Gao, Y. Assessing nitrate and fluoride contaminants in drinking water and their health risk of rural residents living in a semiarid region of Northwest China. Expo. Health 2017, 9, 183-195. [CrossRef]

3. Chen, J.; Wu, H.; Qian, H.; Li, X. Challenges and prospects of sustainable groundwater management in an arid region along the Silk Road economic belt, Northwest China. Int. J. Water Resour. Dev. 2016. [CrossRef]

4. Kumar, M.; Ramanathan, A.L.; Rao, M.S.; Kumar, B. Identification and evaluation of hydrogeochemical processes in the groundwater environment of Delhi, India. Environ. Geol. 2006, 50, 1025-1039. [CrossRef] 
5. Sonkamble, S.; Sahya, A.; Mondal, N.C.; Harikumar, P. Appraisal and evolution of hydrochemical processes from proximity basalt and granite areas of Deccan Volcanic Province (DVP) in India. J. Hydrol. 2012, 438-439, 181-193. [CrossRef]

6. Moya, C.E.; Raiber, M.; Taulis, M.; Cox, M.E. Hydrochemical evolution and groundwater flow processes in the Galilee and Eromanga basins, Great Artesian Basin, Australia: A multivariate statistical approach. Sci. Total Environ. 2015, 508, 411-426. [CrossRef] [PubMed]

7. Brkić, Ž.; Briški, M.; Marković, T. Use of hydrochemistry and isotopes for improving the knowledge of groundwater flow in a semiconfined aquifer system of the Eastern Slavonia (Croatia). Catena 2016, 142, 153-165. [CrossRef]

8. Kim, J.-H.; Kim, K.-H.; Thao, N.T.; Batsaikhan, B.; Yun, S.-T. Hydrochemical assessment of freshening saline groundwater using multiple end-members mixing modeling: A study of Red River delta aquifer, Vietnam. J. Hydrol. 2017, 549, 703-714. [CrossRef]

9. Wei, Y.; Fan, W.; Wang, W.; Deng, L. Identification of nitrate pollution sources of groundwater and analysis of potential pollution paths in loess regions: A case study in Tongchuan region, China. Environ. Earth Sci. 2017, 76, 423. [CrossRef]

10. Li, X. Research of Groundwater Chemical Characteristics and Nitrate Pollution Source of Yaozhou Map-Area. Master's Thesis, Chang'an University, Xi'an, China, 2015. (In Chinese)

11. Chen, J.; Qian, H.; Wu, H. Nitrogen contamination in groundwater in an agricultural region along the New Silk Road, northwest China: Distribution and factors controlling its fate. Environ. Sci. Pollut. Res. 2017, 24, 13154-13167. [CrossRef] [PubMed]

12. Chen, J.; Qian, H.; Wu, H.; Gao, Y.; Li, X. Assessment of arsenic and fluoride pollution in groundwater in Dawukou area, Northwest China and the associated health risk for inhabitants. Environ. Earth Sci. 2017, 76, 314. [CrossRef]

13. Cheng, Y.; Zhang, J.; Peng, J. ArcGIS-based evaluation of geo-hazards at Yaozhou County, Shaanxi, China. J. Rock Mech. Geotech. Eng. 2013, 5, 330-334. [CrossRef]

14. Wei, Y.; Fan, W.; Cao, Y. Experimental study on the vertical deformation of aquifer soils under conditions of withdrawing and recharging of groundwater in Tongchuan region, China. Hydrogeol. J. 2017, 25, 297-309. [CrossRef]

15. Furi, W.; Razack, M.; Abiye, T.A.; Kebede, S.; Legesse, D. Hydrochemical characterization of complex volcanic aquifers in a continental rifted zone: The Middle Awash basin, Ethiopia. Hydrogeol. J. 2012, 20, 385-400. [CrossRef]

16. Rajabpour, H.; Vaezihir, A.; Sedghi, M.H. The North Tabriz Fault, a barrier to groundwater flow in an alluvial aquifer northwest of Tabriz, Iran. Environ. Earth Sci. 2016, 75, 849. [CrossRef]

17. Hagedorn, B.; Whittier, R.B. Solute sources and water mixing in a flashy mountainous stream (Pahsimeroi River, U.S. Rocky Mountains): Implications on chemical weathering rate and groundwater-surface water interaction. Chem. Geol. 2015, 391, 123-137. [CrossRef]

18. Zhuang, J.; Peng, J.; Wang, G.; Iqbal, J.; Wang, Y.; Li, W.; Xu, Q.; Zhu, X. Prediction of rainfall-induced shallow landslides in the Loess Plateau, Yan'an, China, using the TRIGRS model. Earth Surf. Process. Landf. 2017, 42, 915-927. [CrossRef]

19. Wu, H.; Li, X.; Qian, H. Detection of anomalies and changes of rainfall in the Yellow River Basin, China, through two graphical methods. Water 2018, 10, 15. [CrossRef]

20. Wu, H.; Qian, H. Innovative trend analysis of annual and seasonal rainfall and extreme values in Shaanxi, China, since the 1950s. Int. J. Climatol. 2017, 37, 2582-2592. [CrossRef]

21. Peng, J.; Chen, L.; Huang, Q.; Men, Y.; Fan, W.; Yan, J. Physical simulation of ground fissures triggered by underground fault activity. Eng. Geol. 2013, 155, 19-30. [CrossRef]

22. Liu, B.K.; Chen, Y.W.; Zhou, C.K. Hydrogeology Survey Report of Valley Region in Yaoxian County, Shaanxi; Department of Geology and Mineral Resources of Shaanxi Province: Xi'an, China, 1985. (In Chinese)

23. Si, P.Z.; Yu, J.X.; Ge, X.W.; Xue, Y.B. Summary of Geology and Hydrogeology Mapping in Yaoxian County, Shaanxi; Shaanxi Coal Hydrogeology Team: Xi'an, China, 1997. (In Chinese)

24. Ministry of Health of PRC; Standardization Administration of PRC. Standard Examination Methods for Drinking Water (GB/T5750-2006); Standards Press of China: Beijing, China. (In Chinese)

25. Lambrakis, N.; Antonakos, A.; Panagopoulos, G. The use of multicomponent statistical analysis in hydrogeological environmental research. Water Res. 2004, 38, 1862-1872. [CrossRef] [PubMed] 
26. Belkhiri, L.; Boudoukha, A.; Mouni, L.; Baouz, T. Application of multivariate statistical methods and inverse geochemical modeling for characterization of groundwater-A case study: Ain Azel plain (Algeria). Geoderma 2010, 159, 390-398. [CrossRef]

27. Suk, H.; Lee, K.-K. Characterization of a ground water hydrochemical system through multivariate analysis: Clustering into ground water zones. Groundwater 1999, 37, 358-366. [CrossRef]

28. Wu, J.; Li, P.; Qian, H.; Duan, Z.; Zhang, X. Using correlation and multivariate statistical analysis to identify hydrogeochemical processes affecting the major ion chemistry of waters: A case study in Laoheba phosphorite mine in Sichuan, China. Arab. J. Geosci. 2014, 7, 3973-3982. [CrossRef]

29. Askri, B. Hydrochemical processes regulating groundwater quality in the coastal plain of Al Musanaah, Sultanate of Oman. J. Afr. Earth Sci. 2015, 106, 87-98. [CrossRef]

30. Parkhurst, D.; Appelo, C. User's Guide to PHREEQC (Version 2); US Geological Survey: Reston, VA, USA, 1999.

31. Qian, H.; Wu, J.; Zhou, Y.; Li, P. Stable oxygen and hydrogen isotopes as indicators of lake water recharge and evaporation in the lakes of the Yinchuan Plain. Hydrol. Process. 2014, 28, 3554-3562. [CrossRef]

32. Qian, H.; Li, P.; Wu, J.; Zhou, Y. Isotopic characteristics of precipitation, surface and ground waters in the Yinchuan plain, Northwest China. Environ. Earth Sci. 2013, 70, 57-70. [CrossRef]

33. Somaratne, N.; Mustafa, S.; Lawson, J. Use of hydrochemistry, stable isotope, radiocarbon, ${ }^{222} \mathrm{Rn}$ and terrigenic ${ }^{4} \mathrm{He}$ to study the geochemical processes and the mode of vertical leakage to the Gambier Basin tertiary confined sand aquifer, South Australia. Water 2016, 8, 180. [CrossRef]

34. Yin, G.; Ni, S. Deuterium excess parameter evolution in ground water bulletin of mineralogy. Petrol. Geochem. 2001, 20, 409-411. (In Chinese)

35. Vengosh, A.; Hening, S.; Ganor, J.; Mayer, B.; Weyhenmeyer, C.E.; Bullen, T.D.; Paytan, A. New isotopic evidence for the origin of groundwater from the Nubian Sandstone Aquifer in the Negev, Israel. Appl. Geochem. 2007, 22, 1052-1073. [CrossRef]

36. Hagedorn, B.; Cartwright, I. Climatic and lithologic controls on the temporal and spatial variability of $\mathrm{CO}_{2}$ consumption via chemical weathering: An example from the Australian Victorian Alps. Chem. Geol. 2009, 260, 234-253. [CrossRef]

37. Wu, H.; Chen, J.; Qian, H.; Zhang, X. Chemical characteristics and quality assessment of groundwater of exploited aquifers in Beijiao Water Source of Yinchuan, China: A case study for drinking, irrigation, and industrial purposes. J. Chem. N. Y. 2015, 2015, 726340. [CrossRef]

38. Mackenzie, F.J.; Garrells, R.H. Silicates: Reactivity with sea water. Sci. J. 1965, 150, 57-58. [CrossRef] [PubMed]

39. Mayback, M. Global chemical weathering of surficial rocks estimated from river dissolved loads. Am. J. Sci. 1987, 287, 401-428. [CrossRef]

40. Li, P.; Wu, J.; Qian, H. Hydrogeochemical characterization of groundwater in and around a wastewater irrigated forest in the southeastern edge of the Tengger Desert, Northwest China. Expo. Health 2016, 8, 331-348. [CrossRef]

41. Rogers, R.J. Geochemical comparison of groundwater in areas of New England, New York, and Pennsylvania. Groundwater 1989, 27, 690-712. [CrossRef]

42. Rajmohan, N.; Elango, L. Identification and evolution of hydrogeochemical processes in the groundwater environment in an area of the Palar and Cheyyar River Basins, southern India. Environ. Geol. 2004, 46, 47-61. [CrossRef]

43. Lakshmanan, E.; Kannan, R.; Kumar, M.S. Major ion chemistry and identification of hydrogeochemical processes of ground water in a of Kancheepuram district, Tamil Nadu, India. Environ. Geol. 2003, 10, 157-166. [CrossRef]

44. Datta, P.S.; Tyagi, S.K. Major ion chemistry of groundwater in Delhi area: Chemical weathering processes and groundwater flow regime. J. Geol. Soc. India 1996, 47, 179-188.

45. Fisher, R.S.; Mullican, W.F., III. Hydrochemical evolution of sodium-sulfate and sodium-chloride groundwater beneath the northern Chihuahuan Desert, Trans-Pecos, Texas, USA. Hydrogeol. J. 1997, 5, 4-16. [CrossRef]

46. Maya, A.L.; Loucks, M.D. Solute and isotopic geochemistry and groundwater flow in the Central Wasatch Range, Utah. J. Hydrol. 1995, 172, 31-59. [CrossRef]

47. Anders, R.; Mendez, G.O.; Futa, K.; Danskin, W.R. A geochemical approach to determine sources and movement of saline groundwater in a coastal aquifer. Groundwater 2014, 52, 756-768. [CrossRef] [PubMed] 
48. Cartwright, I.; Weaver, T.; Petrides, B. Controls on ${ }^{87} \mathrm{Sr} /{ }^{86} \mathrm{Sr}$ ratios of groundwater in silicate-dominated aquifers: SE Murray Basin, Australia. Chem. Geol. 2007, 246, 107-123. [CrossRef]

49. Yidana, S.M.; Yidana, A. Assessing water quality using water quality index and multivariate analysis. Environ. Earth Sci. 2010, 59, 1461-1473. [CrossRef]

50. Gat, J.R. Comments on the stable isotope method in regional groundwater investigations. Water Resour. Res. 1971, 7, 980-993. [CrossRef] 